\title{
Internationalizing Social Work Education: Models, Methods and Meanings
}

\section{Martha C. Merrill \\ Kent State University}

\section{Caren J. Frost \\ University of Utah}

In her 2008 book, International Social Work: Professional Action in an Interdependent World, Lynne Healy writes, "The student is most likely to find a field experience that provides exactly what the school requires if he or she stays home" (349). In other words, international and intercultural learning requires flexibility, openness, and a willingness to adjust - on the part of the school as well as the student. Yet in social work, as in other professions requiring licensure and preparing professionals to work with vulnerable populations, flexibility is not simply a matter of convincing a department head or registrar to substitute one course for another or to waive a requirement. Becoming a professional social worker requires meeting a set of mandated requirements in a way that becoming a historian or a sociologist does not. Although social workers are encountering increasing amounts of social and cultural difference in their daily practice, certification in the profession nevertheless does - and should - require a known set of competencies and skills. How, then, are social work students to have international and intercultural experiences, without extending the length of their training?

In order to understand the options that are available for internationalizing social work education, and, in particular, internationalizing its field work placements through education abroad, one first must examine the requirements of the field in the U.S., definitions of international social work, and the rationales that have been advanced for internationalizing the field. The models for international student learning that have been proposed and practiced - the prescriptive and the descriptive - need to be reviewed and their plusses and minuses weighed. New options can be considered when the existing situation is known.

\section{Requirements and Definitions}

In order to become a licensed social worker in the United States, a student must graduate from an accredited social work program and take a licensure exam administered by a board in each state. Although licensure is on a state- 
by-state basis, the material covered in the exams follows a fairly standard outline (Association of Social Work Boards, 2008). The titles of the specific licenses, how many hours of supervised practice are required to obtain a particular license, and the mandated qualifications of the supervisor vary from state to state, but generally are quite specific (Association of Social Work Boards, 2008a). For example, in order to become a Licensed Independent Social Worker in the State of Ohio, a person must engage in at least 3000 hours of practice over two years, with not more than 1500 hours in any one year, and be supervised by a Licensed Independent Social Worker who has a supervisor designation.

In the U.S., baccalaureate and master's level social work programs are accredited by the Commission on Accreditation of the Council on Social Work Education (Council on Social Work Education, 2008). The 2008 Standards for Accreditation (Council on Social Work Education, 2008a:8) refer to field work as the "signature pedagogy" of social work education. Standard 2.1.3 (Council, 2008a:9) mandates that Bachelor's-level students must have a minimum of 400 hours in the field, and Master's-level students a minimum of 900. The Standards also indicate the requirements for field supervisors (Council, 2008a:10, Standard 2.1.6). Such requirements are necessary and important, but do not make it easy to design experiences abroad for social work students.

Another complicating issue is that what exactly "international social work" means is not clear. In addition, the roles social workers and other social service professionals play in different societies vary (See Healy, 2008, especially Ch. 8, "Social Work around the World Today," 201-235). The International Federation of Social Workers adopted the following definition of social work in 2000 (Hare, 2004, 409 and 418):

The social work profession promotes social change, problem-solving in human relationships and the empowerment and liberation of people to enhance well-being. Utilizing theories of human behavior and social systems, social work intervenes at the points where people interact with their environments. Principles of human rights and social justice are fundamental to social work.

The Task Force that created this definition included members from countries as diverse as Sweden, Zimbabwe, Singapore, and Colombia, and it took the differing roles and perspectives of social workers in different contexts into careful account in the conceptualization and wording of the definition (Hare, 2004). However, the goal of the Task Force was to create an internationallyaccepted definition of social work, not a definition of international social work. 
The concept of international social work in the U.S. does not have a universally accepted definition. Nagy and Falk (2000, 52) note that although in the 1940's "international social work" was defined as work with international agencies, now "There is no explicit differentiation made between internationalized social work education (social work education with international content and concerns) and education for international social work (training to become an international social worker)."

James Midgley, in an article titled "International Social Work: Resolving Critical Debates in the Profession" (Midgley, 2001) also characterizes the definition of "international social work" as open to debate. He describes (24$25)$ three ways that the term has been defined. The first is as a "field of practice" - international social work means having the skills to work in international agencies or with international populations. The second definition refers to exchanges or contacts between social workers internationally. The third definition relates to an awareness of the contexts of social work practice and the ways in which the issues social workers address may have both international causes and global dimensions. Midgley suggests (25-26) that rather than trying to choose between these definitions, social workers create an overarching definition that provides an inclusive synthesis of all three.

Writing seven years later, Healy $(2008,7)$ finds that the definition issue still is not settled. She explains:

... international social work remains a complex concept ... It is used to refer to comparative social welfare, international practice, cross-cultural knowledge and understanding, intergovernmental work on social welfare, concern and action on social problems, a worldwide collegiality among social workers, professional exchange activities, and a general worldview.

Yet the term has been in use since 1928 (Healy, 2008, 9; Healy, 1999, 15-16), and the issues surrounding international social work have only become more complex. Nevertheless, a contemporary student interested in international issues and competencies in social work education cannot be sure that all listeners will understand what he or she would like to study in precisely the same way.

\section{The Need for International Competencies among Social Workers}

Lorenz (1997, 2, as quoted by Healy, 2008, 4) observes:

"Going beyond the national level" in social work cannot be the personal 
hobby of a few specialists who are dealing with migrant and refugee groups or with ethnic minorities ... or of a few idealists who want to promote international exchanges to widen their horizons and to learn more about methods and practices in other countries. On the contrary, all social work is enmeshed in the global processes of change.

Midgley (2001) elaborates on this theme, noting how market forces and business models are intruding into the caring professions. Globalization, in its definition as a worldwide economic process, he sees as having negative impacts on social policy goals, thus requiring awareness and effort on the part of social workers.

Other authors also enumerate the reasons why social workers need international and intercultural knowledge. Link and Ramanathan (1999, 2) write that "poverty, violence, and social and economic injustice" are universal themes that cause the problems social workers try to eradicate. Asamoah (2003, 2 ) notes that globalization is causing new problems that social workers need to address, such as international migration. Pettys et al, citing a variety of writers (2005, 277) list "reducing ethnocentrism, developing cultural sensitivity, and preparing [students] to work in an interdependent world" as primary reasons that social workers should have international and intercultural knowledge.

Healy (2008:4-6) writes that globalization has created both new responsibilities and new opportunities for social workers. She cites four ways in which the environment of social work practice has been changed by globalization. One is that the migration of populations across national borders has changed the make-up of the caseloads many social workers encounter. A second is that problems such as homelessness and caring for the elderly are occurring in a wide range of societies, and thus solutions may come from nations other than one's own. Third, the actions of one government affect people in other countries. Healy (2008:5) cites the 1986 accident at the nuclear plant at Chernobyl as an example. Fourth, communications technologies have made the sharing of information across borders much easier. These changes mean that social workers have new responsibilities (Healy, 2008, 5-6):

Thus it is important that social workers be prepared to (a) address internationally related case and community problems that arise in their domestic practice, (b) contribute to mutual problem-solving on global social problems, and (c) monitor the impact of their own nation's policies on other countries' and peoples' well-being. 
Thus the need for international education in social work is clear, even if achieving it may be complex.

\section{The Role of Social Work Education in Intercultural Learning}

Higher education should provide students with a mechanism to contextualize world events and to understand their responsibility for engagement and response (Asamoah 2003; Hare 2004; Marga, 2007; Rai 2004). In the field of social work, such contextualization and understanding interfaces with a set of professional values. According to the National Association of Social Workers (2008), social work values include service, social justice, dignity and worth of the person, importance of human relationships, integrity, and competence. The ethical principles underlying each of the values speak to understanding change and working from a current and broader knowledge base to develop solutions appropriate for clients. These values, which are based on the code of ethics for the National Association of Social Workers in the U.S., were developed in a U.S. context. Many of the values transcend that context, but may be interpreted differently in other contexts. Higher education provides the opportunity both for faculty planning programs and for students gaining international and intercultural experiences to reflect upon what values are local and which are universal, rather than permitting them simply to make assumptions about the universality of values and of practice standards (Carrilio \& Mathiesen 2006; Tesoriero 2006; Lindsey 2005). This examination of values and ethical principles should form the basis from which to develop study abroad and/or embedded learning programs. Aiding students in understanding the cultural context of values and helping them to make ethical choices are components of the competencies social workers learn in an educational setting.

The contextualization of world events Marga (2007) examines can be difficult for faculty to accomplish if they have not experienced international learning for themselves and are not clear that the issues faced by social workers are simultaneously global and contextual. Education abroad can empower both students and faculty with a better understanding of who they are and where they fit in the global context. Sandgren (1999) and his colleagues describe how even short-term experiences abroad can initiate reflection that changes how faculty perceive issues and thus how they teach. As Marga $(2007,30)$ stated, "the dominant direction of today's culture is that of exploiting what is given, rather than asking what is possible." In other words, without developing a sense of how problems are handled in other contexts, students may continue to re-use solutions from one context that are not the most effective in another. 
Study abroad programs, according to Younes and Asay (2003) allow students to learn in two different ways: intentionally and incidentally. Intentional learning is the formal learning that the faculty members are expecting from the pedagogical structuring of an experience. In other words, if the faculty member tells students that the purpose of the study abroad program is to learn about social service agencies in another nation and how those agencies handle social welfare issues, he or she expects that students will read, observe, ask questions, and focus on those aspects of the intercultural encounter.

Incidental learning is a "byproduct of some other activity" (Younes \& Asay 2003:142); it is the discoveries a learner makes about him/herself in the process of the intentional learning and the study abroad process. For example, in the three groups of education abroad students Younes and Asay describe, including a social work group that travelled to Scandinavia, one student found renewed enthusiasm for her career choice, while another decided the profession was not the one she wanted (2003:144). Others discovered that group processes required them to exercise different leadership skills than they were accustomed to $(2003: 145)$.

Ward, Bochner, and Furnham (2003/2001) conceive of intercultural learning in terms of the "ABC" model - affective, behavioral, and cognitive learning. In their comprehensive review of research on intercultural adjustment, they devote a chapter to international students. Although Ward, Bochner, and Furnham are focused on longer-term sojourners than those on the study tours Younes and Asay describe, some authors, such as Sandgren (1999) and Spencer and Tuma (2009), have found evidence that for certain populations, even shorter-term experiences can lead to significant learning. Study abroad, then, can support social work values by empowering the learner with new opportunities to discover differing world views and to understand why differing world views are important (Wessel 2007; Fairchild, Pillai \& Noble 2006).

\section{Rationales for Education Abroad}

Writers on education abroad in general have noted similar rationales for intercultural learning. Marjik van der Wende, in a chart in Hans de Wit's Internationalization of Higher Education in the USA and Europe (de Wit, 2002, 100), provides four rationales that have been used to justify education abroad at different times: the political, the economic, the cultural, and the educational. Of course, more than one rationale can come into play at any one time. In the first decade of the $21^{\text {st }}$ century, the U.S. government is sponsoring a "critical languages" program, which provides support for students 
who are studying languages important to U.S. security at locations abroad. This support clearly is a political rationale. One of those languages is Arabic, and regardless of one's political leanings, it seems not to be a great stretch to connect the political rationale to the economic rationale in this regard: oil from Middle Eastern countries where Arabic is spoken is a driver in the U.S. economy. Cultural rationales are among the most traditional rationales for education abroad: students studying art, literature, history, music, and other humanities fields have needed to understand the cultures that shaped the artists and historical figures they study. For example, a student who has visited both St. Petersburg and Moscow will understand the dichotomies Tolstoy suggests in War and Peace much better than one who has not. While all study abroad, hopefully, is educational (although the possibility of what Dewey $(1938 / 1997)$ calls "mis-education," if students' existing perceptions are not examined and interrogated, unfortunately is all too real) the educational rationales for study abroad mean that there are some topics a student simply cannot study in the same way in his or her home location as he or she can in a location abroad. A colleague specializing in tropical ecology could not learn about rain forest plants in quite the same way at his campus in Syracuse as he could at a field station in Puerto Rico. Another colleague, interested in how the use of Russian language is changing in the former Soviet republics in Central Asia, needs to be in Central Asia. He cannot learn what he needs to know in Bloomington, Indiana. Different education abroad program designs can emphasize and respond to different rationales (Rodman and Merrill, 2010).

Despite the example of our colleague who could not study the rainforest while located in the Adirondacks, education abroad traditionally has been the province of humanists and social scientists. One change in the last decade or so is the increase in business students studying abroad—going back to the economic rationale, as economies become globalized, and, to use Friedman's (2005) term, "the world is flat," business students have needed to learn about the rest of the world - and even in some cases, to really understand that there is a rest of the world. A quotation attributed to a number of speakers notes that "The U.S. is the only country in the world that has a friendly neighbor to the north, a friendly neighbor to the south, an enormous ocean to the east, and an enormous ocean to the west." This geographical setting means that U.S. students can be parochial in ways that students in Belgium or Sierra Leone or Ecuador or Cambodia cannot. For most other countries of the world, the next door neighbor is indeed right next door-and does not always wish you well. And the parochialism, in turn, means that many U.S. undergraduate students, who often have a "general education" requirement that students in many other countries completed in secondary school, can use education abroad credits 
as part of that general education, in order to broaden their understanding of the world. For social work students, this might mean that a semester-long education-abroad experience would need to be completed during the first two years of undergraduate studies, whereas the junior year is the more traditional time for semester-long education abroad. By the junior and senior year, being away for a semester often puts a social work student out of sequence with required courses.

\section{International Education in Professional Programs}

What these rationales and educational structures mean is that, in the past, in the U.S. education abroad usually was not part of professional education. Professional education, in fields such as social work or law or pharmacy or engineering, in the U.S. traditionally has been tightly regulated by accrediting and licensing bodies. In many ways, this is as it should be; consumers want to know that an engineer knows how to build a bridge and that a pharmacist knows which chemical compounds interact with which other ones in which ways. However, in the "people professions" or "helping professions," where the profession itself focuses on interaction with others, for example social work, nursing, education, or business, then part of the "skill set" of the profession is understanding other cultures. Social workers, for example, as previously noted, in many cities now encounter a diversity of nationalities that a generation ago they did not: Somalis in Lewiston, Maine; Hmong in Central California; a Russian Christian community in Idaho; Burmese in Utah. Competency in social work practice now means understanding both the specific cultures of the populations with which one works as well as "culture general" concepts such as individualism and collectivism that can help one stop and analyze characteristics of many cultures.

But how can that culture learning — and the necessary affective, behavioral, and cognitive cultural adjustment skills that go along with interaction in such communities (see Ward, Furhnam, and Bochner, 2001/2003) be learned? Professional students rarely can drop anything that's already in their curriculum to spend a substantial period of time abroad, and for most adult students in the U.S. system, often already deeply in debt, extending graduate education for an additional semester or year is not an option. Some professional schools, as noted, have added short-term, faculty-led study tours in the summer to try to resolve this problem, but a ten-day or two week "trip" does not promote real cultural or intercultural understanding for many students, particularly if they are still in the ethno-centric stages of Bennett's Developmental Model of Intercultural Sensitivity (M. J. Bennett, in Paige, 1993). 


\section{Social Work Program Models for International and Intercultural Learning}

Social work educators who wish to infuse international and intercultural content into their degree programs thus face a plethora of challenges: older students with family responsibilities may not be mobile, accreditation and licensure requirements may require certain kinds of experiences or practica of certain lengths; students may have limited foreign language skills; financing time abroad may be a problem. Although various instructors have created courses about international and intercultural issues (see Healy and Asamoah, 1997; Healy, Asamoah, and Hokenstad, 2003; Hokenstad and Midgley, 2004; Link and Healy, 2005; Prigoff, 2000; Ramanathan and Link, 1999), creating experiential courses that actually take place abroad can be a complex process for social work educators. In addition, Skolnik et al (1999:472) report on a study by Raskin (1994) that indicates that social worker educators lack agreement on what the objectives of field work experiences should be. Various writers have discussed program models that address some of these issues, and that also focus on some of the ethical and intercultural issues involved in international fieldwork placements.

Most of the writers on internationalizing social work education focus on practica abroad. Panos et al (2004) surveyed all of the accredited social work programs in the U.S., both bachelor's and master's level $(\mathrm{N}=446)$. They found that $21 \%$ of the surveyed programs had placed students in credit-bearing field placements abroad between 1997 and 2002, but that many of these placements were ad hoc responses to particular situations, rather than structured programs. They write (2004:469), “... the mode number of students placed was one.” However, they also found that a number of programs were trying to encourage repeat placements with the same partners (2004:471). The university placing the most students abroad (75) between 1997 and 2002, Wayne State University in Detroit, placed all of them in Canada (2004:470). Seven of the eight countries in which students were most frequently placed are English-speaking; Mexico is the one exception (2004: 474). Pettys et al (2005:279), working with some of the same data, noted that some U.S. universities close to the Canadian and Mexican borders used just one application for field placements, regardless of whether the placement was in the U.S. or just across the border.

Skolnik et al (1999) did the inverse: rather than surveying international field placements by U.S. schools, they surveyed the 400 members of the International Association of Schools of Social Work (IASSW) outside the U.S. about their field placement practices. Schools of social work in 67 countries responded (1999:474). In 31 of those countries, an agency external to the school sets standards for social work education, and in 25 of those 31 countries, 
the standards set include standards for field instruction. Thus meeting the needs of one country by doing a field placement in another is likely to be difficult. In addition, while all U.S. schools have practicum requirements at both the bachelor's and master's level, Skolnik et al (1999:478) discovered that in many schools outside the U.S., graduate programs do not require practica:

While over $95 \%$ of bachelor's and diploma-granting programs report practicum requirements, only $39 \%$ of master's level and 3\%of doctoral programs do. This leads to the unexplored question of whether or not programs without practicum requirements consider prior school, employment or volunteer experience as a substitute, or if there are no practice requirements at all.

Placement requirements also differ in the number of hours involved (ranging from 200 to 1000), the number of placements required (ranging from one to four), and whether the placements consist of observation, quick rotation through an number of situations, or a semester or year-long residency in one setting (1999:479). These factors, too, make it complicated for a student in Country A to fulfill a practicum requirement by attending a partner school in Country B. Healy (2008: 349) concurs on the difficulties:

Social work is defined differently in different countries. Educational standards and content vary considerably between countries. Because the functions of social workers vary, the tasks expected of practicum students will not be a perfect fit with those expected by the sending school.

Rai (2004) surveyed fifteen U.S. schools and identified two kinds of international placements (217): "One type of placement is for those foreign students who have made arrangements with their U.S.-based schools to do internships in their own country. The other type is for U.S. students interested in doing fieldwork in a foreign country." Most of the students in his study already had international experiences or connections and actively sought out international placements; they, and not their universities, were the initiators (218). Nevertheless, Rai notes (220):

Generally, American students go abroad with little or no preparation to function in the host culture. They assume that academic ability, technical expertise and linguistic competence will give them the 
necessary intercultural skills to make a successful transition in a new culture. But lack of cultural training often has disastrous consequences (Weinman and Bragg, 1993).

Razack (2002) similarly is concerned about students' lack of knowledge, but frames that concern in terms of students' not understanding imperialism, oppression, and marginalization. When students speak of "helping" rather than transforming lives and social change, Razack believes that the students are not fully understanding the social and economic contexts in which they are working.

Pettys and his colleagues (2005) conducted in-depth qualitative interviews at 21 U.S. universities and identified four types of field placements. The first is similar to Rai's first category, and the other three subdivide his second category. Pettys et al (2005: 282) describe the categories as follows:

1. the independent/one-time placement model,

2. the neighbor-country model,

3. the on-site model, and

4. the exchange/reciprocal model

The independent/one-time model (2005:282), unlike Rai's first model, is not limited solely to international students, although they may be part of the population. In the Pettys model, the one-time placement is initiated by a student with a particular interest or a faculty member with a particular connection. In the neighbor-country model (2005:283), students often were citizens or residents of the country in which the field placement was located, but were close enough to the U.S. university that they could return for regular field-placement seminars on campus. In the on-site model (2005: 283 and 286), the university employed an on-site supervisor in-country, often an alumnus/a of the U.S. program or a professor emeritus/a. The supervisor thus had knowledge of both the U.S. program and local conditions. Students could be placed in a range of agencies and the supervisor could conduct relevant seminars for the group. The fourth model, the exchange model, (2005:2867) may seem familiar to international education practitioners, but in the social work context, the idea, as Pettys et al describe it, is a little different. The exchange may be a link between a university and an agency, rather than between two universities. Implied in the discussion is that a church-related university may have connections with agencies in a host country that are supported by the same religious denomination. 
Lyons and Ramanathan (1999) discuss assumptions and rationales of field placements from a European point of view, as well as pragmatics such as where to go, when to go, liability insurance, and the necessary preparatory work such as travel plans, arranging accommodations, and students' health care precautions, and present nine brief case studies of European students, some with more successful placements and some with less successful ones. They consider (1999: 179) bilateral agreements between schools of social work in different countries, with the options of concurrent enrollment (classroom instruction and practica simultaneously), "block" enrollment (seminars to support the field placement, but not theory classes at the same time), and the "delayed model," in which students first do a short practicum on campus, before going out to work in the community.

Mathiesen and Lager (2007), who have experience with the Florida International Volunteer Corps and have worked with student placements in the Caribbean, have developed a seven-step model to guide the creation and implementation of international placements:

The process of developing the exchanges should include the following communication steps for both host and guest nation: (1) establish a feedback loop with potential participants; (2) gain an overview of the other country; (3) provide orientation at micro, mezzo and macro levels; (4) identify gains; (5) consider costs; (6) clarify expectations; and (7) establish roles for the student, field liaison, and field supervisor. (280)

While considering pragmatic issues such as costs, their model continuously emphasizes communication and reciprocity between the parties involved. Of course, much of this is familiar territory for education abroad offices involved in exchanges and in service-learning abroad. Similarly, Healy (2008: 349-350) lists characteristics of good exchange programs that will not surprise most international educators: "considerable preparatory work," strong linkages and clarity of expectations between partners, and programs to prepare and debrief students. Lyons and Ramanathan (1999: 185-186), however, are among the few who discuss the need for re-entry programming.

Poole and Davis (2006:61-62) are critical of the lack of evaluation of programs abroad: Social work differs little, however, from other schools and departments in the need to find better ways to measure outcomes in study abroad programs. Healy \& Hokenstad's (2003) recent review of 13 international social work collaborations in higher education reveals thevirtual absence of systematic research to evaluate program effectiveness. 
They attribute this lack of evaluation to the dual pulls for rigorously collected, objective data and for rich, contextual information that captures the individual experience and learning. However, in the $21^{\text {st }}$ century, education abroad, as with all of higher education, is subject to increasing calls to document its outcomes.

\section{Internationalization Models Other than Fieldwork}

Although international field work placements are the most prevalent form of international education among social work students in the U.S,. and those placements are likely to be the form of international education study abroad professionals most frequently will be involved with, other mechanisms for internationalizing social work education have been developed. Healy, Asamoah, and Hokenstad (2003) edited a volume with eleven case studies of international collaboration in social work education. While many of the programs described involve exchanges, for both faculty and students, other options exist. Doreen Elliott and her colleagues depict the development of a "binational, bilingual" social work doctoral program involving the University of Texas at Arlington and the Universidad Autonoma de Nuevo Leon in Mexico (pp. 71-79). M.C. "Terry" Hokenstad tells the story of how Case Western Reserve University collaborated with the Eotvos Lorand University in Hungary, assisting in the re-establishment of social service professions and the education needed for them after the Berlin Wall came down (pp. 45-50). Similarly, Robert Constable, Regina Kulys, and W. David Harrison portray a long-term, multi-institutional project to "educate the educators" (91) at the Center for Professional Education in Social Work in Kaunas, Lithuania (9199).

Additionally, of course, as noted above, internationally-focused coursework can take place on the home campus. Link and Healy (2005) have edited a collection of sixteen syllabi and eight modules to help U.S. students learn about international and global social issues. The courses include those that provide broad overviews, such as "Global Perspectives on Human Need" and "Comparative Social Welfare," as well as those with more specific emphases, such as human rights, violence against women, civil society and the role of NGOs, and sweatshops. The modules address issues such as sustainable development, women's rights, racism, and immigration and refugee issues.

Of particular interest to education abroad professionals is the course titled "War and Peace in Bosnia," organized by faculty at the University of Wisconsin-Superior for students in social work, history, and political science (Dwyer, Bahm, and Dokhanchi, 2005, 185-190). The course is not a field 
placement, but rather is "a three-week immersion in the history, politics, and social welfare structure of Bosnia before, during, and after the recent war" (185). Students are selected through an application and interview process and participate in a twelve-hour orientation course. The program includes required readings, journal-writing, and reaction papers, as well as an in-country service project.

\section{Silos and Silences}

Although the issues of licensure and accreditation uniquely affect social work, many of the other factors that make adding an international and intercultural dimension to the social work curriculum challenging are factors shared by other disciplines and programs in higher education. Meeting the needs of older students, what can be learned on a short-term program, changing program designs, pre-departure and re-entry programs, culture learning in general, debates about ethical issues regarding students from wealthier societies doing social service work in poorer countries, questioning the relative emphases on service and learning and on learning vs. social transformation, financing, liability issues, emergency evacuation: all of these debates and discussions have infused the international education community for years. The need for conversations across disciplines, specializations, and programs is widespread, but throughout higher education, "silos" separate knowledge communities, even when such silences force different disciplines to reinvent the wheel.

For example, service-learning programs and social work field education programs share many of the same challenges, yet, on most campuses and in most of the literature, the two remain distinct. (One exception is Guevara and Ylvisaker's chapter in Healy, Asamoah, and Hokenstad, 2005, 81-90.) The 21-volume "Service-Learning in the Disciplines" series addresses fields as diverse as accounting, architecture, composition, and environmental science, but not social work. ${ }^{1}$ Similarly, although service-learning programs increasingly take place in international locations, and, it might be argued, service-learning programs in general involve students in entering new "cultures," broadly conceived (e.g. the culture of a nursing home), little writing explicitly addresses the intercultural learning aspects of service-learning, including what educators should know in order to facilitate such learning. ${ }^{2}$

In a parallel fashion, little communication seems to take place between the "silos" of social work and intercultural communication, although the two fields share both theoretical and pragmatic, outcomes-oriented interests. Clearly, many international social work practitioners are aware of intercultural issues. Rambally (1999:491), for example, describes a halfway house for psychiatric patients in Barbados that unsuccessfully used an imported, 
culturally inappropriate methodology, focusing only on the individual and not involving families and the broader community. However, some of the "classics" in the intercultural communication field rarely are mentioned in the international social work literature. These might include Allport's contact theory (Allport, 1954; Dixon et al, 2005; Pettigrew, 1998; Pettigrew and Tropp, 2000), Janet Bennett's work on marginality (J. M. Bennett, 1993), Milton Bennett's Developmental Model of Intercultural Sensitivity (M. J. Bennett, 1993), Darla Deardorff's definitions of intercultural competence (2008), Ned Hall's high and low context communication styles and work on monochronic and polychronic time (1984), Geert Hofstede's cultural dimensions (2001), Kluckhohn and Strodtbeck's variations in value orientations (1961), TingToomey on facework (2004) and intercultural conflict resolution (2001), and Ward, Bochner, and Furnham's affective, behavioral, and cognitive model of intercultural adjustment (2003/2001). The Intercultural Communication Institute's "Resources" page lists many more sources (Intercultural Communication Institute, 2010).

Based on a review of the literature and our own observations in a variety of contexts over a number of years, it seems safe to say that although social work educators often use short-term, faculty-led study tours to provide international experiences for adult students, most of these educators seem unaware of Spencer and Tuma's Guide to Short-Term Programs Abroad, already in its second edition (Spencer and Tuma, 2009), as well as other education abroad publications and resources available from NAFSA, the Forum of Education Abroad, and other organizations and publishers. Pragmatic issues such as finances, liability insurance, and emergency evacuation procedures often have been addressed by international education offices on campus, and social work educators could save time and agitation by consulting with those offices. On the other hand, many social work educators have considered issues of international field placements and student supervision in depth, and as education abroad offices place added emphasis on internships and work experience abroad, they likely could learn from their counterparts in social work.

With regard to program models, although at least three collections of syllabi addressing various aspects of international social work have been published (Healy and Asamoah, 1997; Healy, Asamoah, \& Hokenstad, 2003; Link and Healy, 2005), none of them contains examples of what international educators would call an "embedded" course - a course in which the experiential piece, the education abroad, occurs either during spring break or immediately after the end of a semester (usually spring semester, but the experience also could occur in a "J-term," for schools which use a 4-1-4 calendar). The experience abroad thus is "embedded" in a full semester of academic course 
work, thereby providing the students with a substantial contextual analysis and a depth of understanding that often is missing from shorter-term experiences abroad. Although a number of the short-term faculty-led programs abroad in social work, such as the "War and Peace in Bosnia" course (Dwyer, Bahm, and Dokhanchi, 2005), include required pre-departure orientations, readings, and reflection activities, and although other models, such as semester-long field work abroad supported by theoretical courses or reflective seminars (Lyons and Ramanathan, 1999) provide strong academic support for an experience abroad, the embedding of a shorter experience abroad into an on-campus course seems not to be a commonly used model in social work education. Given that many social work students may find it difficult to be away for a full semester, and that curricular and licensing requirements also may make longer-term experiences abroad difficult to design, the embedded program design may be one that some social work educators wish to consider.

\section{Conclusions}

Education abroad program designers who wish to work with colleagues interested in internationalizing social work education need to be concerned with both general and discipline-specific issues. Social work students resemble many other adult and professional students in their need for shortterm programs that meet specific requirements, resulting in the frequency of faculty-led summer programs. Many international education offices will have policies and procedures for such programs in place: travel specialists, emergency contact procedures, liability waivers, and like probably already exist, permitting the social work faculty person to focus on learning objectives and in-country connections. Not all of these policies and procedures may be designed to accommodate graduate students, however, and many social work students looking for experiences abroad may be MSW students. Policies and procedures may also be designed for classroom-based learning abroad, and social work education abroad is likely to include an experiential component.

In addition, internationalizing social work education has its own specifics as well. Not only should the international education office staff be aware of the relevant accreditation and licensure requirements for social work students, but also they need to recognize that not everyone interprets "international social work" in the same way. Education abroad staff people would be well advised to discuss with social work colleagues at some length both the definition of international social work the program or professor is using and the learning objectives he or she is hoping to achieve. Clarity between partners on campus on such points is as essential as is clarity with partners abroad.

The issue of learning objectives and evidence of learning (Poole, 2006) 
raises another concern. Education abroad program design has never been "one size fits all." Rodman and Merrill (2010) have compared designing international programs to spinning the dials on a combination lock: the combination of factors that will open learning for an anthropology student at Warren Wilson College is different than the combination that will open learning for a nursing student at Rockland Community College or a history student at Kennesaw State. Education abroad always has been characterized by a diversity of means and methods. However, in the $21^{\text {st }}$ century, education abroad, like higher education overall, is massifying. More higher education institutions are at least encouraging, if not requiring, more students with more diverse backgrounds to study abroad. Simultaneously, both regional and specialized accrediting agencies and some state governments and coordinating boards are asking for more and more information about the outcomes of learning. Designing education abroad programs to meet the needs of social work students and providing evidence of the learning that has taken place is one example of the new sets of skills that are being asked of international education professionals. In reflecting on those demands, and extrapolating from them, an education abroad professional may conclude that not only is the profession of social work changing and becoming more internationalized, but also the profession of international education is changing and demanding more skills and knowledge in both academic disciplines and in the evaluation of learning outcomes. Silos and silence between colleagues and disciplines are likely to be dysfunctional in international education's future.

\section{References}

Allport, G. W. (1954) The Nature of Prejudice Reading, MA: Addison-Wesley

Asamoah, Y. (2003). International collaboration in social work education:

Overview. In L. Healy, Y. Asamoah, and M. C. Hokenstad, eds. Models of International Collaboration in Social Work Education (pp. 1-14).

Alexandria, VA: Council on Social Work Education.

Association of Social Work Boards (2008) Examination Content Outlines.

Retrieved from the website of the Association of Social Work Boards: http://www.aswb.org/SWLE/examoutlines.asp on February 26, 2010. Association of Social Work Boards (2008a). Experience and supervision requirements. Retrieved from the website of the Association of Social Work Boards: https://www.datapathdesign.com/ASWB/Laws/Prod/cgibin/LawWebRpts2DLL.dll/EXEC/1/1fsxc3s1b0bh4f1agx8n30y0kwo4 on February 26, 2010.

Bennett, J. M. (1993) Cultural marginality: Identity issues in intercultural training. In R. M. Paige, ed. Education for the intercultural experience. 
(pp. 109-136) Yarmouth, ME: Intercultural Press

Bennett, M. J. (1993) Towards ethnorelativism: A developmental model of intercultural sensitivity. In R. M. Paige, ed. Education for the intercultural experience. (pp. 109-136) Yarmouth, ME: Intercultural Press

Carrilio, T. \& Mathiesen, S. (2006). Developing a cross border, multidisciplinary educational collaboration. Social Work Education 25(6), 633-644.

Constable, R., Kulys, R. \& Harrison, W. D. (2003) Developing Social Work Education in Lithuania: An International Consultation Project. In Healy, L., Asamoah, Y., \& Hokenstad, M.C., eds. Models of international collaboration in social work education. Alexandria, VA: Council on Social Work Education

Council on Social Work Education (2008). 2008 Education Policy and Accreditation Handbook Arlington, VA: Author. Retrieved from: http:// www.cswe.org/Accreditation/Handbook.aspx Accessed February 24, 2010.

Council on Social Work Education (2008a). 2008 Standards for Accreditation Arlington, VA: Author Retrieved from: http://www.cswe.org/File. aspx?id=13780 Accessed February 24, 2010.

Deardorff, D. K. (2008) Intercultural Competence: A Definition, Model and Implications for Education Abroad. In V. Savicki, ed. Intercultural Competence and Transformation: Theory, Research and Application in International Education (pp.32-52) Sterling, VA: Stylus Publishing. Dewey, J. (1938/1997) Education and Experience New York: Touchstone Books

De Wit, H. (2002) Internationalization of Higher Education in the USA and Europe Westport, CT: Greenwood Publishing

Dixon, J., Durrheim, K., \& Tredoux, C. (2005) Beyond the optimal contact strategy: A reality check for the contact hypothesis. American Psychologist. 60 (697-711)

Dwyer, J. A., Bahm, K., \& Dokhanchi, H. (2005) War and Peace in Bosnia. In Link, R. J. \& Healy, L. M., eds. Teaching International Content: Curriculum Resources for Social Work Education Alexandria, VA: Council on Social Work Education/CSWE Press

Elliott, D. et al. (2003) A Binational, Bilingual Doctoral Program in Social Work: The Collaboration of the University of Texas at Arlington and Universidad Autonoma de Nuevo Leon, Mexico. In Healy, L., Asamoah, Y., \& Hokenstad, M.C., eds. Models of international collaboration in social work education. Alexandria, VA: Council on Social Work Education 
Fairchild, S.A., Pillai, V.K. \& Noble, C. (2006). The impact of a social work study abroad program in Australia on multicultural learning. International Social Work 49(3), 390-401.

Friedman, T. (2005) The World is Flat New York: Farrar, Straus, and Giroux Guevara, J. A. \& Ylvisaker, R. S. (2003) Home and Host Models of Collaboration for Service Learning: Grand Valley State University Programs in El Salvador and South Africa. In In Healy, L., Asamoah, Y., \& Hokenstad, M.C., eds. Models of international collaboration in social work education. Alexandria, VA: Council on Social Work Education Hall, E. T. (1984) The dance of life: The other dimension of time New York: Anchor/Random House

Hare, I. (2004). Defining social work for the $21^{\text {st }}$ century: The International Federation of Social Workers' revised definition of social work. International Social Work 47(3): 407-424.

Healy, L. (1999) International Social Work Curriculum in Historical Perspective. In C.S. Ramanathan \& R. J. Link, eds. All Our Futures: Principles and Resources for Social Work Practice in a Global Era Belmont: Brooks/Cole Wadsworth (An International Thomson Publishing Company)

Healy, L. (2008) International Social Work: Professional Action in an Interdependent World Oxford/New York: Oxford University Press Healy, L. \& Asamoah,Y. (1997) Global Perspectives in Social Work Education: A Collection of Course Outlines on International Aspects of Social Work. Alexandria, VA: Council on Social Work Education

Healy, L., Asamoah, Y., \& Hokenstad, M.C., eds. (2003). Models of international collaboration in social work education. Alexandria, VA: Council on Social Work Education.

Hofstede, G. (2001). Culture's Consequences (2e) Thousand Oaks, CA: Sage Hokenstad, M. C. (2003) Collaboration in an Era of Social Transition: The Eotvos Lorand University, Hungary - Case Western Reserve University Connection. In Healy, L., Asamoah, Y., \& Hokenstad, M.C., eds. Models of international collaboration in social work education. Alexandria, VA: Council on Social Work Education

Hokenstad, M.C. and Midgley, J., eds. (2004) Lessons from Abroad: Adapting International Social Welfare Innovations Washington, DC: National Association of Social Workers Press

Intercultural Communication Institute (2010). Resources. Retrieved from the web site of the Intercultural Communication Institute http://www. intercultural.org/resources.php on February 27, 2010. 
Kluckhohn, F. R. \& Strodtbeck, F. L. (1961) Variations in value orientations. Evanston, IL: Row, Peterson

Lindsey, E.W. (2005). Study abroad and values development in social work students. Journal of Social Work Education 41(2), 229-249.

Link, R. J. \& Healy, L. M., eds. (2005) Teaching International Content: Curriculum Resources for Social Work Education Alexandria, VA: Council on Social Work Education/CSWE Press

Link, R. J. \& Ramanathan, C. S. (1999) Introduction. In C.S. Ramanathan $\&$ R. J. Link, eds. All Our Futures: Principles and Resources for Social Work Practice in a Global Era Belmont, CA: Brooks/Cole Wadsworth Lyons, K. \& Ramanathan, C. S. (1999) Models of Field Practice in Global Settings. In C.S. Ramanathan \& R. J. Link, eds. All Our Futures: Principles and Resources for Social Work Practice in a Global Era Belmont, CA: Brooks/Cole Wadsworth

Marga, A. (2007). The University of the $21^{\text {st }}$ Century: Challenges. Keynote Comments at $18^{\text {th }}$ AUDEM Conference in Cluj-Napoca, Romania. Retrieved from the website of the Alliance of Universities for Democracy (AUDEM): http://www.audem.org/conferences/ conference18/ on February 26, 2010.

Mathiesen, S. G. \& Lager, P (2007, April). A Model for Developing International Student Exchanges. Social Work Education 26 (3), 280291.

Merrill, M. C. (2005) The Cultural and Intercultural Contexts of ServiceLearning. In K. Chisholm, ed. Knowing and Doing: The Theory and Practice of Service-Learning New York: International Partnership for Service-Learning and Leadership, pp. 177-201 Merrill, M. C., and Pusch, M. D. (2007) Apples, Oranges, and Kumys: Models for Research on Students Doing Intercultural Service-Learning. In S. Billig \& S. Gelmon, eds., From Passion to Objectivity: International and Cross-Disciplinary Perspectives on Service-Learning Research Greenwich, CT: Information Age Publishers, pp. 21-40.

Midgley, J. (2001) International Social Work: Resolving Critical Debates in the Profession. Journal of Social Work 1 (1): 21-35

Nagy, G. \& Falk, D. (2000) Dilemmas in international and cross-cultural social work education. International Social Work 43 (1): 49-60

National Association of Social Workers (2008). Code of Ethics. Retrieved from the National Association of Social Workers website: http://www. socialworkers.org/pubs/code/code.asp on February 22, 2010. 
Paige, R.M. (1993) On the nature of intercultural experience and intercultural education. In R. M. Paige, ed. Education for the intercultural experience. (pp. 1-20) Yarmouth, ME: Intercultural Press

Panos, P., Pettys, G., Cox, S. \& Jones-Hart, E. (2004). Research notes-survey of international field education placements of accredited social work education programs. Journal of Social Work Education. 40(3), 467-478.

Pettigrew, T. F. (1998) Intergroup contact theory. Annual Review of Psychology. 49 (65-85)

Pettigrew, T. F. \& Tropp, L. R. (2000) Does intergroup contact reduce prejudice? Recent meta-analytic findings. In S. Oskamp, ed. Reducing prejudice and discrimination (pp. 93-114) Mahwah, NJ: Lawrence Erlbaum

Pettys, G.L. et al. (2005) Four models of international field placement. International Social Work 48 (3): 277-288

Poole, D.L. \& Davis, T.S. (2006). Concept mapping to measure outcomes in study abroad programs. Social Work Education 25(1), 61-77.

Prigoff, A. (2000) Economics for Social Workers Belmont, CA: Brooks/Cole Thomson

Pusch, M. D. \& Merrill, M. C. (2008) Reflection, Reciprocity, Responsibility, and Committed Relativism: Intercultural Development through International Service-Learning. In V. Savicki, ed. Intercultural Competence and Transformation: Theory, Research and Application in International Education (pp. 297- 321) Sterling, VA: Stylus Publishing. Rai, G.S. (2004). International fieldwork experience: A survey of U.S. schools. International Social Work 47(2): 213-226.

Rambally, R.E. (1999). Field education in a developing country: promoting organizational change and social development. International Social Work, 42(4), 485-496

Razack, N. (2002). A critical examination of international student exchanges. International Social Work. 45(2), 485-496.

Rodman, R. \& Merrill, M. (2010) Unlocking Study Abroad Potential: Design Models, Methods and Masters. In W. W. Hoffa and S. C. DePaul, eds. A History of U.S. Study Abroad 1965 - Present. Carlisle, PA: Frontiers: The Interdisciplinary Journal of Study Abroad

Sandgren, D. et al. (1999, Spring) How International Experience Affects Teaching: Understanding the Impact of Faculty Study Abroad. Journal of Studies in International Education (33-56)

Skolnik, L. Wayne, J. \& Raskin, M. (1999). A worldwide view of field education structures and curricula. International Social Work, 42(4), 471-483. 
Spencer, S. \& Tuma, K. (2009) Guide to Short-Term Programs Abroad (2e) Washington, DC: NAFSA: Association of International Educators Tesoriero, F. (2006). Personal growth towards intercultural competence through an international field education programme. Australian Social Work 59(2), 126-140.

Ting-Toomey, S. \& Chung, L. C. (2004) Understanding Intercultural Communication New York: Oxford University Press Ting-Toomey, S. \& Oetzel, J. G. (2001) Managing Intercultural Conflict Effectively Thousand Oaks, CA: Sage

Ward, C., Bochner, S., \& Furnham, A. (2003 reprint of 2001 original). The Psychology of Culture Shock 2e London and New York: Routledge Wessel, N. (2007). Integrating service learning into the study abroad program: U.S. sociology students in Mexico. Journal of Studies in International Education 11(1): 73-89.

Younes, M.N. \& Asay, S.M. (2003). The world as a classroom: The Impact of International Study Experiences on College Students. College Teaching 51(4): 141-147.

\section{Endnotes}

${ }^{1}$ The series, originally published by the American Association for Higher Education (AAHE), now is published by Stylus, www.StylusPub.com

${ }^{2}$ Relevant sources include Pusch and Merrill (2008), Merrill and Pusch (2007), and Merrill (2005). 